\title{
Synthesis of Acetylenic Derivatives of a Substituted 1, 3, 4-Thiadiazole as Antibacterial Agents
}

Anwar A. Tamer ${ }^{*}, 1$ and Ahlam J. Qassir*

*Department of Pharmaceutical Chemistry, College of Pharmacy, University of Baghdad, Baghdad, Iraq

\section{Abstract}

Thiadiazole is a heterocyclic compound that exhibits a wide variety of pharmacological activities such as anticancer, antibacterial, antifungal, antimicrobial, anti-inflammatory, analgesic and anticonvulsant.

2, 5 disubstituted 1, 3, 4-thiadiazole constitutes an important class of compounds for new drug development because it acts as "hydrogen binding domain" and "two-electron donor system." It also serves as a constrained pharmacophore.

This research highlights the recently synthesized Schiff base and mannich base derivatives and investigation of their chemical and biological behavior. Depending on this information's new derivatives of 1, 3, 4-thiadiazole were synthesized and in the hope of having some activities as antibacterial and antifungal. These are:

1. N-(5-((4-(piperidin-1-yl) but-2-yn-1-yl) thio)-1, 3, 4-thiadiazol-2-yl) acetamide compound (4).

2. 1-(4-chlorophenyl)-N-(5-((4-(piperidin-1-yl) but-2-yn-1-yl) thio)-1, 3, 4 thiadiazol-2-yl) methanimine compound (6).

3. 1-(4-chlorophenyl)-N-(5-(prop-2-yn-1-ylthio)-1, 3,4thiadiazol-2-yl)methanimine compound(7). The characterization of mentioned compounds was performed by FTIR spectroscopy, ${ }^{1} \mathrm{HNMR}$, measurements of their physical properties, and studying of biological activity of the synthesized compounds by well diffusion method.

Keywords: 1, 3, 4 Thiadiazole, Schiff base, Mannich base

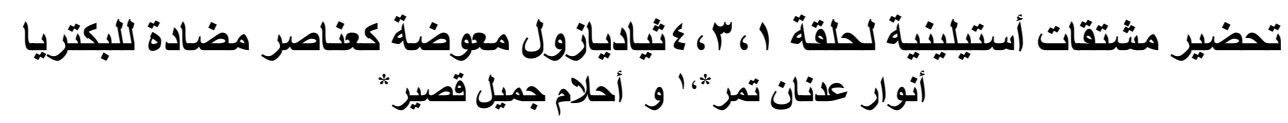

$$
\text { الخلاصة الكيمياء الصيدلانية،كلية الصيدلة، جامعة بغداد، بغداد، العراق. }
$$

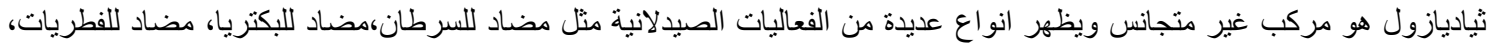

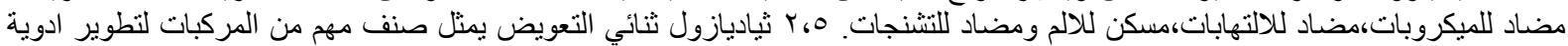

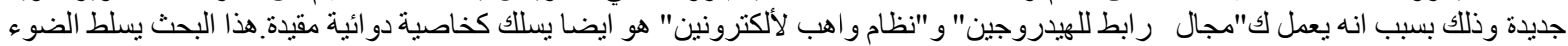

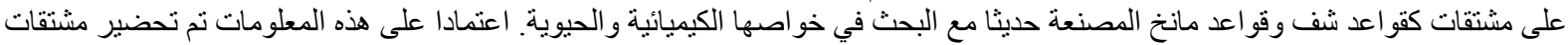

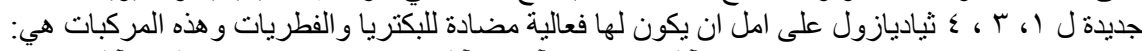

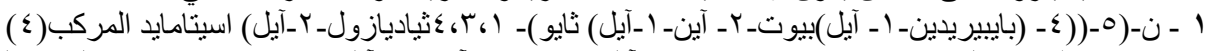

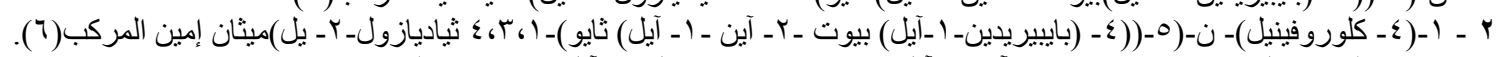

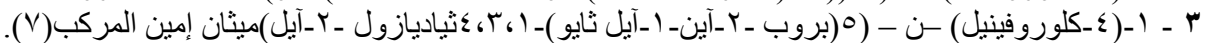

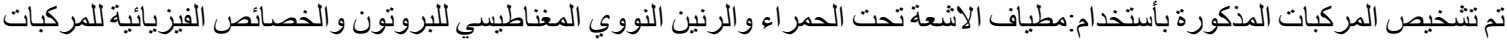

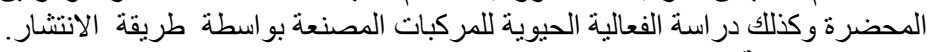

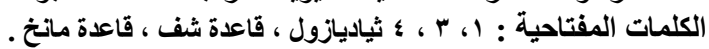

\section{Introduction}

Heterocyclic compounds are the cyclic organic compounds which contain at least one heteroatom, the most common heteroatoms are the nitrogen, oxygen, and sulfur but heterocyclic rings containing other heteroatoms are also widely known (1).

Heterocyclic compounds are considered as one of the principal classes of organic compounds, which are used in many biological fields, due to their activities. Biological molecules such as DNA and RNA, chlorophyll, hemoglobin, vitamins and many more contain the heterocyclic ring in the significant skeleton (2). Heterocycles are used in the development of several pharmaceutically essential compounds in a wide manner. The nitrogen and sulfur heterocyclic systems are important because of their physicochemical properties like lipophilicity with relevance to the design of new drugs ${ }^{(3)}$.

${ }^{1}$ Corresponding author E-mail: noor.adnan85@yahoo.com

Received: $12 / 12 / 2018$

Accepted: 27 /2/ 2019

Iraqi Journal of Pharmaceutical Sciences 
Thiadiazole nuclei have antimicrobial, antiinflammatory, anticancer, anticonvulsant, antidepressant, antioxidant, radio protective, antileishmanial activities , antimicrobial, antitubercular, antifungal, analgesic, oxidative inhibitors, anti $\mathrm{H}$ pylori, herbicides, dyes, lubricants and analytical reagents ${ }^{(4) . .(6)}$. The Mannich reaction is a crucial $\mathrm{C}-\mathrm{C}$ bond forming reaction that is widely used in the synthesis of many biologically active natural compounds ${ }^{(7)}$.

Mannich reactions are three component condensation reactions involving carbonyl compounds, which exist as enol-keto tautomeric forms, formaldehyde and a primary or secondary amine $^{(8)}$.

Mannich bases are known to have potent activities like anti-inflammatory, anticancer, antibacterial, antifungal, anticonvulsant, antitubercular, analgesic, antiviral, antihistamine activities and in agrochemicals such as plant growth regulators ${ }^{(9) \ldots(11)}$.

Schiff bases are an essential class of compounds due to their flexibility, structural similarities with natural biological substances and the presence of imine

$(-\mathrm{N}=\mathrm{CH}-)$ which is involved in the mechanism of transformation and racemization reaction in the biological system. These novel compounds could also act as valuable ligands whose biological activity has been shown to increase on complexation ${ }^{(12)}$.

Also, they have a wide range of biological activities especially anti-bacterial ${ }^{(13)}$, anti-inflammatory ${ }^{(14)}$, anti-fungal (15), anti-tumor (16) anti-oxidant (17), antimicrobial, anthelmintic, anti-inflammatory, analgesic antipyretic, antitubercular, diuretic, hypoglycemic, anticonvulsant, anti-HIV, cytotoxic (18)

Recently, the severe infectious diseases caused by gram positive and gram negative pathogenic bacteria have inflated to threat level around the world. This increases, as well as the emergence of bacteria immune to ordinarily used antibiotics, has resulted in the need to develop new categories of antibacterial agents to conflict infections ${ }^{(19)}$.

\section{Material and Methods}

Chemicals used during the synthesis were supplied by hyper-chem (China). Completion of reactions and the purity of compounds were monitored by thin-layer chromatography (TLC), using Silica gel GF254 (type 60) pre-coated aluminum sheets, Merck (Germany) exposed to UV$254 \mathrm{~nm}$ light. Two solvent systems were used ethyl acetate: hexane (3:7) and methanol: hexane (8:2). Melting points were detected by using Stuart SMP3 melting point apparatus in open capillary tubes, and are uncorrected. The infrared spectra were performed in $\mathrm{KBr}$ disc, $\left(v, \mathrm{~cm}^{-1}\right)$, using FTIR Spectrophotometer (Shimadzu, WQF-520, Japan).
${ }^{1} \mathrm{HNMR}$ spectra were obtained on (NMRready-60 spectrophotometer, 60MHz Nanalysis corp, Canada) using deuterated acetone and DMSOd6 as solvents and TMS as an internal standard.

\section{Chemical synthesis}

The target compound were synthesized by multistep reaction as shown in scheme 1 .

Synthesis of 2-amino-5-mercapto 1, 3, 4 thiadiazole (1) ${ }^{(20)}$ :

Thiosemicarbazide $(0.043$ mole, $4 \mathrm{~g})$ was suspended in absolute ethanol $(30 \mathrm{ml})$ in a round flask $(250 \mathrm{ml})$, anhydrous sodium carbonate $(0.021$ mole, $2.23 \mathrm{~g})$ and carbon disulfide $(0.125$ mole, $9.5 \mathrm{~g})$ were then added respectively with continues stirring. Reflux to the reaction mixture was done for five hours; then allowed to cool to room temperature and filtered.

The filtrate was subjected to evaporation under vacuum then cold distilled water $(90 \mathrm{ml})$ was added, followed by acidification with concentrated $\mathrm{HCl}$ drop by drop, a white-yellowish precipitate was formed, the precipitate was obtained by filtration, and washed with distilled water, re-crystallized using hot distilled water.

Product 2-amino-5-mercapto 1, 3, 4 thiadiazole (1) was yellow powder, yield $70 \%$, M.P: $230-232^{\circ} \mathrm{C}$, reported $\left(230-232^{\circ} \mathrm{C}\right)$, IR: (3325 and 3244) $\mathrm{NH}_{2}$ stretching, (1604) $\mathrm{NH}_{2}$ bending, (1550) $\mathrm{C}=\mathrm{N}$ stretching, (640) C-S stretching.

Synthesis of 5-(2-propynylsulfanyl)-1, 3, 4thiadiazol-2-ylamine (2) (2I)

To a sterried solution of 2-amino-5-mercapto $1,3,4$ thiadiazole compound (1)

$(0.1$ mole, $13.3 \mathrm{~g})$ in absolute ethanol $(200 \mathrm{ml})$, a solution of potassium hydroxide

(0.1mole, 5.6g) in $100 \mathrm{ml}$ absolute ethanol was added. Then to the reaction mixture propargyl bromide ( 0.11 mole $13.3 \mathrm{~g}$ ) was added drop wise.

Reflux to the reaction mixture was done for one hour then the reaction mixture was cooled to room temperature, filtered. The filtrate was poured into cold D.W (150 ml), yellow precipitate separated out. The product (2) was yellow crystals, yield $68 \%$, M.P:126- $129^{\circ} \mathrm{C}$, IR: (3294) for

$\equiv \underline{\mathrm{C}-\mathrm{H}}$, (3294 and 3263) $\mathrm{NH}_{2}$ stretching, (2978 and2785) $\mathrm{CH}_{2}$ stretching, (2360) $\mathrm{C} \equiv \mathrm{C}$ stretching, (1608) $\mathrm{NH}_{2}$ bending, (1492) $\mathrm{CH}_{2}$ bending.

\section{Synthesis of N-(5-(prop-2-yn-1-ylthio)- 1,3,4thiadiazol-2-yl)acetamide(3) ${ }^{(22)}$ :}

A mixture of compound (2) (0.022 mole, $3.762 \mathrm{~g}$ ) and acetic anhydride containing $0.5 \mathrm{ml}$ of concentrated $\mathrm{H}_{2} \mathrm{SO}_{4}(0.11$ mole, $10 \mathrm{ml})$, was heated in a steam bath for 1 hour. Then the mixture was cooled then poured into $60 \mathrm{ml}$ of cold water. After that, the mixture was boiled to decompose the excess of acetic anhydride. The mixture was left to cool then filtered, and the product was washed with cold water and recrystallized from D.W. 
Compound (3) was off-white powder, yield $70 \%$, M.P:200-203 ${ }^{\circ}$ C, IR: (3255) stretching of (C-H) of triple bond, (3155) $\mathrm{NH}$ amide stretching, (2866 and2785) stretching of $\mathrm{CH}_{2}$ and $\mathrm{CH}_{3}$, (2360) stretching of $\mathrm{C} \equiv \mathrm{C}, \quad(1689) \quad(\mathrm{C}=\mathrm{O})$ of amide stretching, (1558) NH amide bending, (1446-1337) bending of $\mathrm{CH}_{2}$ and $\left(\mathrm{CH}_{3}\right)$.

Synthesis of mannich base: N-(5-((4-(piperidin-1yl) but - $2-y n-1-y l$ ) thio ) - $1,3,4$ - thiadiazol2-yl)acetamide $(4)^{(21)}$

To the solution of compound (3) ( 0.003 mole, $0.639 \mathrm{~g})$ in free peroxide dioxane $(10 \mathrm{ml})$, paraformaldehyde $(0.003$ mole, $0.09 \mathrm{~g})$ was added. Then piperidine $(0.003$ mole, $0.3 \mathrm{~g})$ and cuprous chloride (catalytic amount) were added. Heat the reaction mixture was done by using a water bath at $70-80^{\circ} \mathrm{C}$ for 3 hours. Finally, the reaction mixture was cooled down to room temperature, filtered; the filtrate was poured into ice water mixture $(25 \mathrm{ml})$.

The product compound (4) was brown powder, yield $56 \%$, M.P: $138-140^{\circ} \mathrm{C}$,

IR : ( 3140) stretching of NH amide, (2897 and 2762) stretching of $\mathrm{C}-\mathrm{H}\left(\mathrm{CH}_{2}\right)$ and $\left(\mathrm{CH}_{3}\right)$, (2360) stretching of $\mathrm{C} \equiv \mathrm{C}$, (1701) stretching of $(\mathrm{C}=\mathrm{O})$ of amide, (1593) bending of $\mathrm{NH}$ amide, (1435) and (1369) bending of $\mathrm{C}-\mathrm{H}\left(\mathrm{CH}_{2}\right)$ and $\left(\mathrm{CH}_{3}\right)$.

The ${ }^{1} \mathrm{HNMR}$ spectrum of the compound (4) displayed a peak at $(\delta=1.30 \mathrm{ppm})$ as multiplate for 6 protons of piperidine ring, multiplate peak at $(\delta=2.13 \mathrm{ppm})$ for $4 \mathrm{H}$ of piperidine, singlet peak at $(\delta=2.22 \mathrm{ppm}) 3 \mathrm{H}$ for $\mathrm{CH}_{3}$ of amide, singlet peak at $(\delta=3.15 \mathrm{ppm}) \quad 2 \mathrm{H}$ for $\mathrm{CH}_{2}$ beside $\mathrm{N}$, singlet peak at $(\delta=4.04 \mathrm{ppm}) \quad 2 \mathrm{H}$ for $\mathrm{CH}_{2}$ beside $\mathrm{S}$, and singlet peak at $(\delta=12.75 \mathrm{ppm}) 1 \mathrm{H}$ for amide $\mathrm{N}-\mathrm{H}$.

\section{Synthesis of deprotected compound 5-(4- (piperidin-1-yl)but-2-yn-1-yl)thio)-1,3,4-thiadiazol -2 - $\operatorname{amine}(5)^{(23)}$}

A mixture of protected compound (4) (0.01 mole, $3 \mathrm{~g})$, concentrated $\mathrm{HCl}(6 \mathrm{ml})$, and ethanol (40 $\mathrm{ml}$ ) was refluxed for 3 hours in oil bath. After that, the reaction mixture was subjected for evaporation to get rid of a part of ethanol. Then filtered, the precipitate obtained was recrystallized from D.W. The product (5) was off-white powder, yield 64.5\%, M.P:118-120 ${ }^{\circ} \mathrm{C}$, I.R: , (3379 and 3307) $\mathrm{NH}_{2}$ stretching, (2947 and 2881) stretching of C-H of $\left(\mathrm{CH}_{2}\right),(2364) \mathrm{C} \equiv \mathrm{C}$ stretching, (1666 and 1589) $\mathrm{NH}_{2}$ bending, (1462) bending of $\mathrm{C}-\mathrm{H}\left(\mathrm{CH}_{2}\right)$.

\section{Synthesis of 1-(4-chlorophenyl)-N-(5-((4- (piperidin-1-yl)but-2-yn-1-yl)thio)-1,3,4 thiadiazol $-2-y l)$ methanimine compound $(6)^{(24)}$}

Compound (5) (0.002 mole, 0.536g) was suspended in $25 \mathrm{ml}$ of absolute ethanol. $P$ chlorobenzaldehyde $(0.002$ mole, $0.28 \mathrm{~g})$ in $25 \mathrm{ml}$ of absolute ethanol solution was added with few drops of glacial acetic acid. The mixture was then refluxed for 8 hours and later left it overnight at room temperature. The solvent was evaporated in vacuum to get 1-(4-chlorophenyl)-N-(5-((4-(piperidin-1-yl) but-2-yn-1-yl) thio)-1, 3, 4 thiadiazol-2-yl) methanimine compound (6). Compound (6) was recrystallized from methanol.

The compound (6) was gray powder, yield $48 \%$, M.P: $247-250{ }^{\circ} \mathrm{C}$, I.R: (3070) stretching of C$\mathrm{H}$ of aromatic ring,(2947 and 2881) stretching of C$\mathrm{H} \quad\left(\mathrm{CH}_{2}\right), \quad(2360) \mathrm{C} \equiv \mathrm{C}$ stretching, (1700) $\mathrm{C}-\mathrm{H}$ stretching of $\mathrm{N}=\mathrm{C}($ imine $), \quad(1593$ and 1442) $\mathrm{C}=\mathrm{C}$ stretching of aromatic ring, (1500) bending $\mathrm{C}$ $\mathrm{H}\left(\mathrm{CH}_{2}\right)$, (1037) in plane bending of $\mathrm{C}-\mathrm{H}$ of aromatic ring, (860) out of plane bending of C-H of aromatic ring, (686) $\mathrm{C}=\mathrm{C}$ bending of aromatic ring. 1HNMR for Compound (6) recorded the following important signals, $(\delta=1.29 \mathrm{ppm})$ as a multiplate peak attributed to $6 \mathrm{H}$ of piperidine ring. A triplet peak at $\delta=(2.04 \mathrm{ppm}) 4 \mathrm{H}$ of piperidine ring beside $\mathrm{N}$, singlet peak at $(\delta=3.02 \mathrm{ppm}) 2 \mathrm{H}$ for $\mathrm{CH}_{2}$ beside $\mathrm{S}$ and $2 \mathrm{H}$ beside $\mathrm{N}$ overlapped, $\mathrm{C}-\mathrm{H}$ proton of $\mathrm{C}=\mathrm{N}$ appear as singlet peak at $(\delta=10.05 \mathrm{ppm}) .(\delta=7.48$ and $7.61 \mathrm{ppm})$ as singlet peak for aromatic $\mathrm{H}$ ortho to $\mathrm{Cl},(\delta=7.98$ and $8.11 \mathrm{ppm})$ as singlet peak for aromatic $\mathrm{H}$ meta to $\mathrm{Cl}$.

Synthesis of Schiff base derivatives (1-(4chlorophenyl)-N-(5-(prop-2-yn-1-ylthio)-1, 3, 4 thiadiazol $-2-y l)$ methanimine compound (7) ${ }^{(24)}$ Compound (2) (0.002 mole, 0.342g) was suspended in $25 \mathrm{ml}$ of absolute ethanol. $P$ chlorobenzaldehyde ( 0.002 mole, $0.28 \mathrm{~g})$ in $25 \mathrm{ml}$ of absolute ethanol solution was added with few drops of glacial acetic acid. The mixture was refluxed for 8 hours left overnight. The solvent was evaporated in vacuum and the residue was recrystallized from methanol.

The product (7) was off-white powder, yield $56 \%$, M.P: $106-110^{\circ} \mathrm{C}$, IR (3271) $\equiv \underline{\mathrm{C}-\mathrm{H}}$ stretching, (3093) C-H stretching of aromatic ring, (2947 and 2835) stretching of $\mathrm{C}-\mathrm{H}\left(\mathrm{CH}_{2}\right), \quad(2360) \quad \mathrm{C} \equiv \mathrm{C}$ stretching, (1697) $\mathrm{C}-\mathrm{H}$ of $\mathrm{N}=\mathrm{C}$ stretching (imine), (1585 and 1423) $\mathrm{C}=\mathrm{C}$ of aromatic ring stretching, (1489) bending of $\mathrm{C}-\mathrm{H}\left(\mathrm{CH}_{2}\right),(1014$ in plane bending of $\mathrm{C}-\mathrm{H}$ of aromatic ring, (850)out of plane bending of $\mathrm{C}-\mathrm{H}$ of aromatic ring, (700) $\mathrm{C}=\mathrm{C}$ of aromatic ring bending.

${ }^{1} \mathrm{HNMR}$ for Compound (7) recorded the following important signals, $(\delta=3.84 \mathrm{ppm})$ for $2 \mathrm{H}$ of $\mathrm{CH}_{2}$ beside $\mathrm{S}$ and $\mathrm{C}-\mathrm{H}$ binded to triple bond, singlet peak at $(\delta=7.33 \mathrm{ppm}) 4 \mathrm{H}$ of aromatic protons, and peak at $(\delta=8.96 \mathrm{ppm})$ for $1 \mathrm{H}$ of $\mathrm{H}-\mathrm{C}=\mathrm{N}$ as a singlet.

\section{Antimicrobial activity}

The antimicrobial activity of the final compounds was evaluated in the University of Baghdad / College of Education for Pure SciencesIbn Al-Haitham by the Advisory Office of the Central Service Laboratory.A preliminary antibacterial have been carried using the well diffusion method. The synthesized compounds were evaluated for their antimicrobial activity in vitro 
against three types of tested microorganisms (Staph. aureus., and Bacillus subtilis as a Gram-positive bacteria) and (klebsiella pneomonae, and E. coli) as a Gram-negative bacteria) were clinically activated and maintained on nutrient agar for examining antibacterial activity. Ampicillin was used as a standard drug for antibacterial activity.

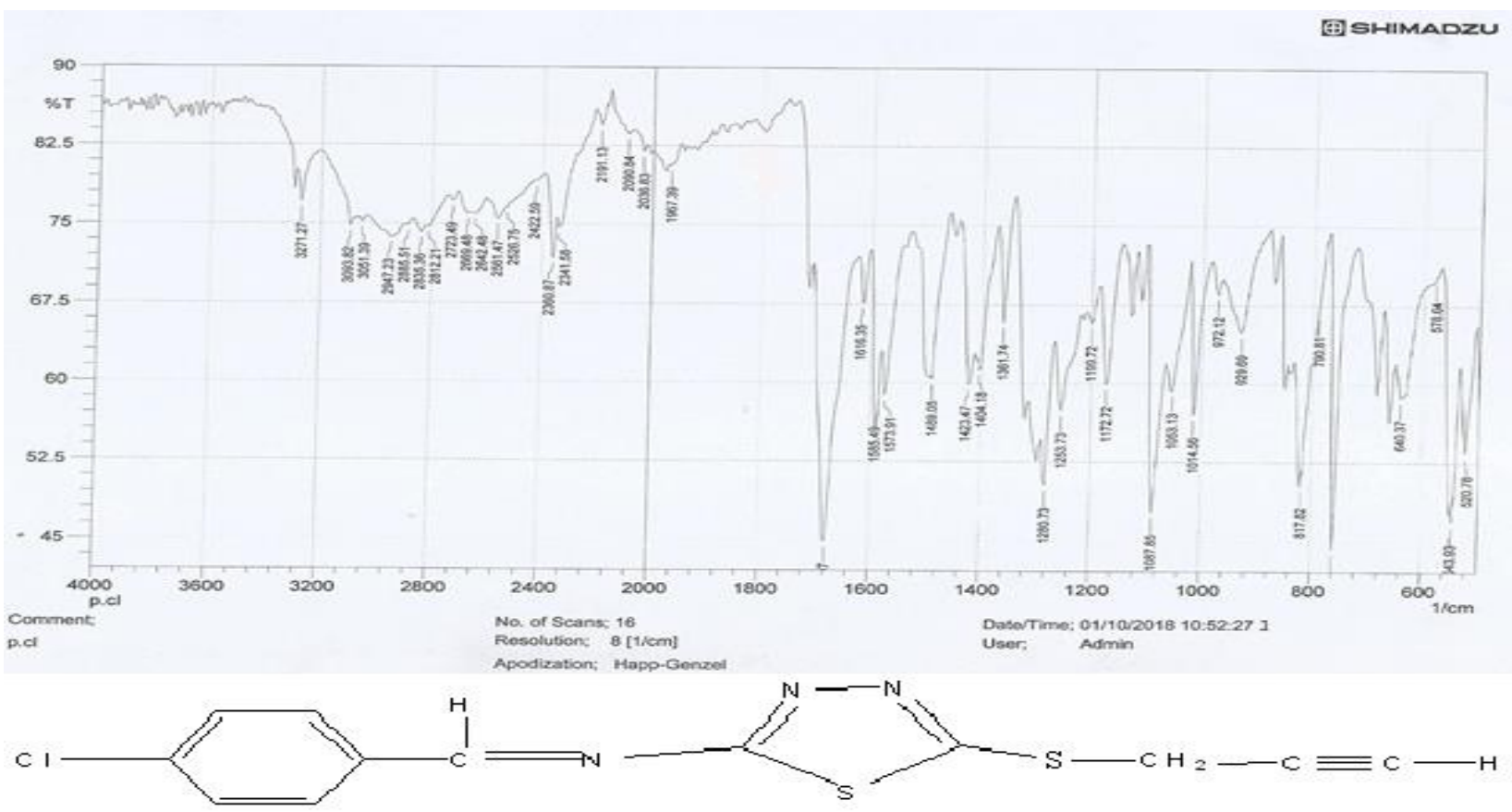

1 -(4 -ch1oropheny1)- $N-(5-($ prop-2-yn-1-y1th io) $-1,3,4$-th ia diazo1-2-y1)methan im ine

IR of compound (7)

\section{Result and Discussion}

Synthesis of compound (1)

The 2-amino-5-mercapto-1, 3, 4- thiadiazole was synthesized by steps of reactions starting from thiosemicarbazide with carbon disulfide in basic medium ${ }^{(25)}$.

\section{Synthesis of compound (2)}

Compound (2) was prepared by alkylating the potassium salt of compound (1) with propargyl bromide. It is logical to assume that the alkylation step followed an $\mathrm{S}_{\mathrm{N}} 2$ mechanism.

The reaction is started by nucleophilic attack of the sulfide anion on the propargyl bromide affording the desired alkylated thiadiazole derivative. No allylic rearrangement was observed ${ }^{(26)}$.

\section{Synthesis of compound (3)}

In the acetylation of compound (2), where this step includes the synthesis of amide; it was done by treatment of an amine with acetic anhydride in the presence of a few drops of sulphuric acid as catalyst. Switching of the amino group into the acetamido group by acetylation modifies the interaction of the nitrogen lone pair with the $\pi$-electron system of the aromatic ring so that the ring is less powerfully activated toward electrophilic attack $^{(27)}$.

\section{Synthesis of compound (4)}

Mannich reaction is a nucleophilic addition reaction that involves the condensation of a compound with active hydrogen(s), with an amine (primary or secondary) and formaldehyde (any aldehyde) ${ }^{(9)}$.

\section{Synthesis of compound (5)}

Acid hydrolysis reaction occurs by nucleophilic addition of water to the protonated amide, followed by transfer of a proton from oxygen to nitrogen to make the nitrogen a better leaving group and for subsequent elimination. The steps are reversible with the equilibrium shifted towards the product by the protonation of the $\mathrm{NH} 2$ in the final step $^{(28)}$.

\section{Synthesis of compound (6) and (7)}

The mechanism of Schiff base formation is a reversible, acid catalyzed process, begins with nucleophilic addition of the primary amine to a carbonyl group (aldehyde or ketone) followed by a transfer of a proton from nitrogen to oxygen to yield neutral amino alcohol or carbinolamine. Protonation of the carbinolamine oxygen by an acid catalyst then converting the $(-\mathrm{OH})$ group into a better leaving group (-OH2), and E1- like loss of water produces an iminium ion which after the loss of a proton from nitrogen gives the Schiff base and regenerate the acid catalyst to afford compounds (6) and (7) ${ }^{(29)(30)}$. 


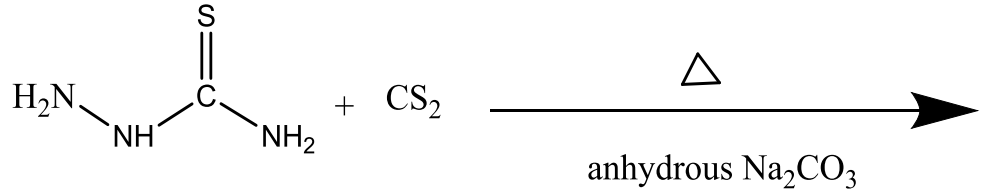
anhydrous $\mathrm{Na}_{2} \mathrm{CO}_{3}$<smiles>Nc1nnc(S)s1</smiles>

(1)

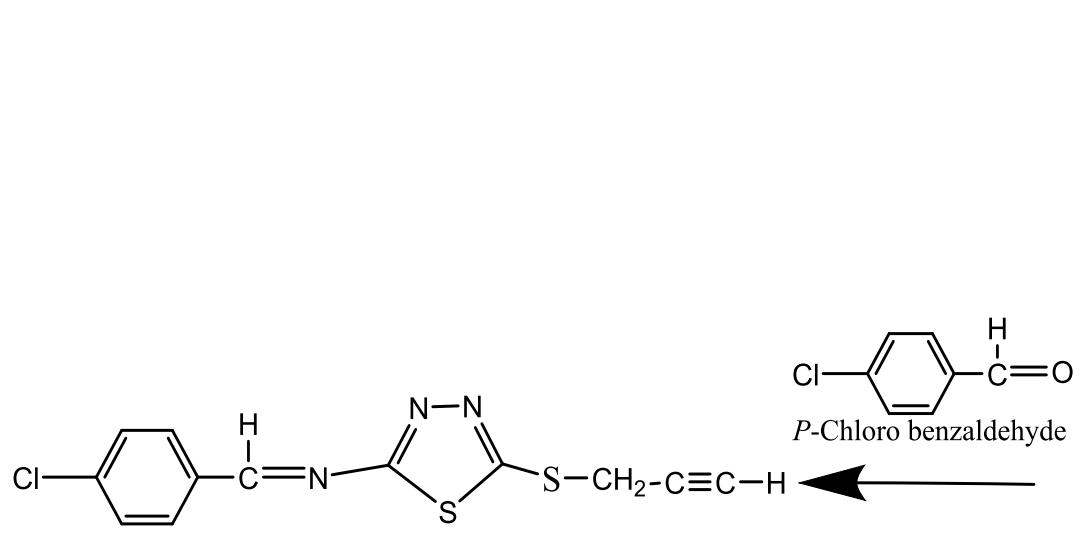

(7)

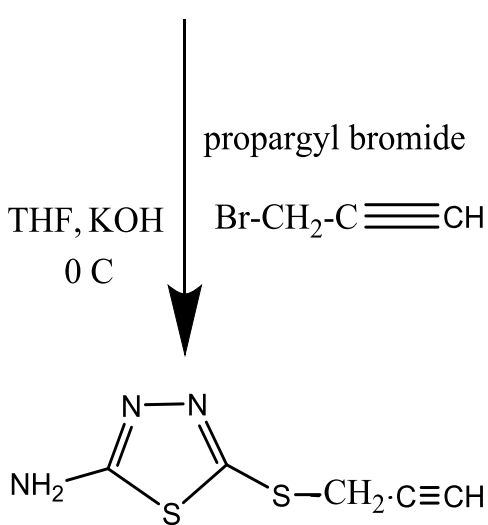

(2)

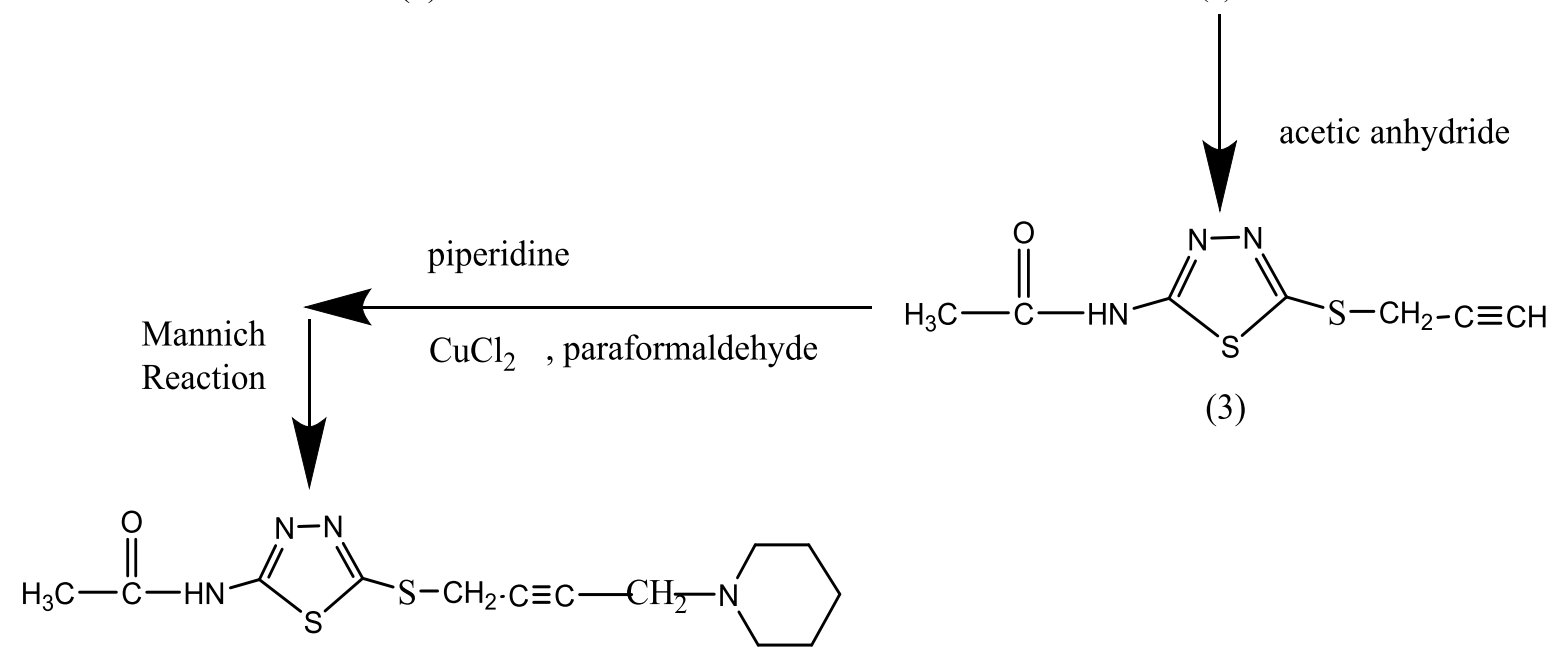

(4)

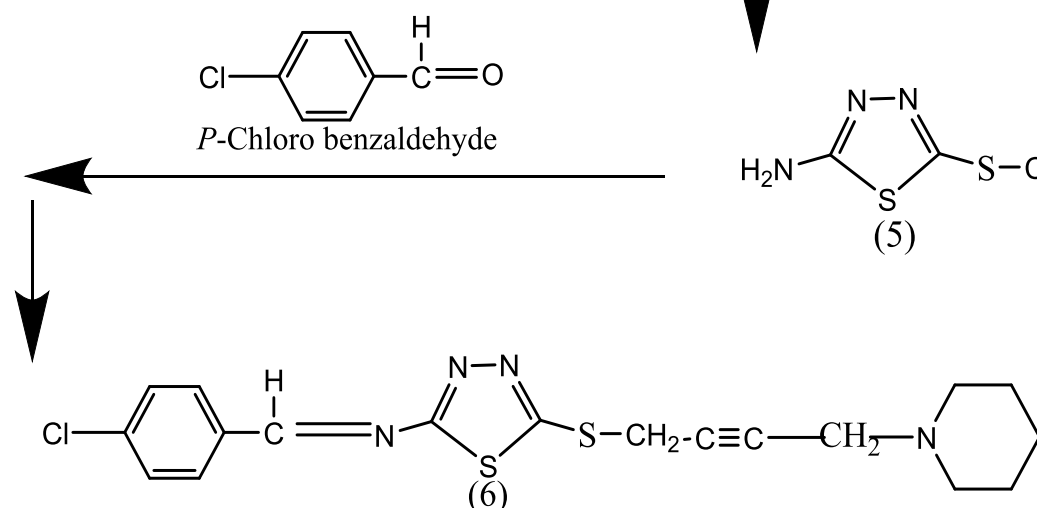

(6)

Scheme (1) synthesis of compounds (1) to (7) 
Antibacterial activity

Table (1) The antibacterial activities of synthesized compounds.

\begin{tabular}{||c|c|c|c|c|c||}
\hline Compound & $\begin{array}{c}\text { Conc. } \\
\mathbf{m g} / \mathbf{m l}\end{array}$ & $\begin{array}{c}\text { Klebsiella } \\
\text { Pneumonia } \\
\text { G-ve }\end{array}$ & E.coli & $\begin{array}{c}\text { Bacillus } \\
\text { Subtilis } \\
\mathbf{G}^{+} \mathbf{v e}\end{array}$ & $\begin{array}{c}\text { Staphylococcus } \\
\text { Aureus } \\
\mathbf{G}^{+} \mathbf{v e}\end{array}$ \\
\hline Comp.(4) & 0.01 & - & 13 & 13 & - \\
\hline Comp.(6) & 0.01 & 13 & 15 & 11 & - \\
\hline Comp.(7) & 0.01 & 13 & 15 & 13 & 24 \\
\hline $\begin{array}{c}\text { Ampicillin } \\
\text { Std. }\end{array}$ & 0.01 & - & - & - & 25 \\
\hline Comp.(4) & 0.02 & 16 & 16 & 16 & - \\
\hline Comp.(6) & 0.02 & 17 & 20 & 16 & 25 \\
\hline Comp.(7) & 0.02 & 19 & 17 & 17 & 25 \\
\hline $\begin{array}{c}\text { Ampicillin } \\
\text { Std. }\end{array}$ & 0.02 & - & - & - & \\
\hline
\end{tabular}

$(-)=$ No activity, $(+)=$ slightly active (Inhibition Zone in between 5-10 $\mathrm{mm}),(++)=$ moderately active (Inhibition Zone in between 10-15 mm), (+++) =highly active (Inhibition Zone More Than $15 \mathrm{~mm}$ ).

The recorded data in Table (1) lead to the following conclusions:

All the synthesized compounds showed antimicrobial activity against $\mathrm{G}\left({ }^{+} \mathrm{ve}\right)$ and $\mathrm{G}$ ('ve) bacteria, but some of them showed no activity against (staphylococcus aureas) (compound 4 and compound 6) at concentration (0.01) $\mathrm{mg} / \mathrm{ml}$ and even in concentration $(0.02 \mathrm{mg} / \mathrm{ml})$. Compound (7) showed activity against previously mentioned $\mathrm{G}$ $\left.{ }^{+} \mathrm{ve}\right)$ (staphylococcus aureas) but at higher conc. showed higher antibacterial activity and it is Schiff base derivative, its benzene ring containing an ewithdrawing group $(\mathrm{Cl})$ at the para position

For compounds (6) which are a combination of Mannich base and Schiff base derivative showed moderate to higher antibacterial activity at both concentrations against tested bacteria.

\section{Conclusions}

New derivatives of 2-amino 5-mercapto1, 3, 4 thiadiazole were successfully synthesized using the conventional method. The synthesis of these proposed compounds was successfully performed by the stated procedures as previously described. The results obtained from this investigation were achieved according to the data shown by the physical and chemical analysis including (TLC, melting point, FTIR and 1HNMR analysis).

Compound 4, 6 \& 7 exhibit good antimicrobial activity comparable with marketable compounds. The antimicrobial evaluation indicated that the newly synthesized compounds showed moderate to high antimicrobial activity in comparison to Ampicillin for gram-positive bacteria and also have highest anti-microbial activity for gram negative bacteria. The compound (7) showed an excellent antimicrobial activity, and highest activity against staphylococcus areus compared to ampicillin.

\section{Acknowledgments}

The authors gratefully thank the College of Pharmacy, University of Baghdad, for supporting this research.

\section{References}

1. Mishra G, Singh AK, Jyoti K. Review article on 1, 3, 4-thiadiazole derivatives and its pharmacological activities. Int J Chem Tech Res. 2011; 3:1380-93.

2. Al-Mulla A. A Review: Biological Importance of Heterocyclic Compounds. Der Pharma Chemica. 2017; 9(13):141-7.

3. Balaji K, Bhatt PR, Mallika D, Jha AN. Design, synthesis and antimicrobial evaluation of some mannich base derivative of 2 (2-substituted)-5amino-thiadiazoles. International Journal of Pharmacy and Pharmaceutical Sciences. 2015;7:145-9.

4. Kokila. P, Sarju. P, Rinku. P, Rekha. P. A Simple and Efficient Procedure for Synthesis of Biologically Active 1,2,4-Triazolo-[3,4-b]1,3,4-thiadiazole -2-aryl-thiazolidine-4-one Derivatives. Res. J. Chem. Sci.2011; vol. 1, 1821.

5. Bhuva H, Sahu D, Shah B, Modi DC, Patel MB. Biological profile of thiadiazole. Pharmacol Online. 2011;1:528-45.

6. Singh. A.K, Mishra. G, Jyoti.K, Review on Biological Activities of 1,3,4ThiadiazoleDerivatives Journal of Applied Pharmaceutical Science; 2011: VOL.5, 44-49.

7. Barta P, Fülöp F, Szatmári I. Mannich baseconnected syntheses mediated by ortho-quinone methides. Beilstein journal of organic chemistry. 2018 Mar 6;14(1):560-75.

8. Demirbas A, Sahin D, Demirbas N, Karaoglu SA. Synthesis of some new 1, 3, 4-thiadiazol-2ylmethyl-1, 2, 4-triazole derivatives and 
investigation of their antimicrobial activities. European journal of medicinal chemistry. 2009 Jul 1;44(7):2896-903.

9. Bala S, Sharma N, Kajal A, Kamboj S, Saini V. Mannich bases: an important pharmacophore in the present scenario. International journal of medicinal chemistry. 2014;2014.

10. Manjula PS, Sarojini BK, Narayana B, Raj CD. An exploration on the synthesis and bioapplications of derivatives of heterocyclic Mannich bases. Journal of Fundamental and Applied Sciences. 2016;8(1):115-75.

11. A. Balakrishnan, Dr. A. Sankar. Study on the Synthesis, Characterization and antimicrobial activity of the New Mannich Base Benzimidazolyl Phenyl Methyl Acetamide and its Metal Complexes.IJPPR human journal. 2017; vol.10(2),62-68.

12. Prasad S, Chandan S, Prasad N. Synthesis and characterization of thiadiazole containing Schiff base: Antimicrobial activity.

13. Sahu R, Thakur DS, Kashyap P. Schiff base: An overview of its medicinal chemistry potential for new drug molecules. International Journal of Pharmaceutical Sciences and Nanotechnology. 2012;5:1757-64.

14. Sobola AO, Watkins GM, van Brecht B. Synthesis, characterization and biological study of $\mathrm{Cu}$ (II) complexes of aminopyridine and aminomethylpyridine SAmanullah M, Sadozai SK, Rehman W, Hassan Z, Rauf A, Iqbal M. Cytotoxic, antibacterial activity and physicochemical properties of some acid catalyzed Schiff bases. African Journal of Biotechnology. 2011;10(2):209-13. schiff bases. J. Serb. Chem. Soc.. 2018 Jan 19.

15. Fasina TM. Synthesis and Antimicrobial Activity of Schiff Bases Derived from Substituted Salicylaldehyde with 2-aminophenol and 2-aminothiophenol. Journal of Scientific Research and Development (JSRD). 2013 Jan $1 ; 14(1)$.

16. Amanullah M, Sadozai SK, Rehman W, Hassan Z, Rauf A, Iqbal M. Cytotoxic, antibacterial activity and physicochemical properties of some acid catalyzed Schiff bases. African Journal of Biotechnology. 2011;10(2):209-13. Naskar AR, Singha TA, Guria TA, Singh J, Kumar AB, Maity TK. Synthesis, characterization, and evaluation of anticancer activity of some new Schiff bases of 1, 3, 4-thiadiazole derivatives. International Journal of Pharmacy and Pharmaceutical Sciences. 2015;7(3):397-402.

17. Naskar AR, Singha TA, Guria TA, Singh J, Kumar AB, Maity TK. Synthesis, characterization, and evaluation of anticancer activity of some new Schiff bases of 1, 3, 4thiadiazole derivatives. International Journal of Pharmacy and Pharmaceutical Sciences. 2015;7(3):397-402.
18. Rudrapal M, De B. Chemistry and biological importance of heterocyclic Schiff's bases. International Research Journal of Pure and Applied Chemistry. 2013 Jul 1;3(3):232.

19. Vinita G, Sanchita S, Gupta YK. Synthesis and Antimicrobial Activity of some Salicylaldehyde Schiff bases of 2-aminopyridine. Research Journal of Chemical Sciences. 2013;3(09):26-9.

20. Petrow V, Stephenson O, Thomas AJ, Wild AM. 302. Preparation and hydrolysis of some derivatives of 1: 3: 4-thiadiazole. Journal of the Chemical Society (Resumed). 1958:1508-13.

21. Al-Khuzaie MG, Al-Majidi SM. Synthesis, characterization, and evaluation antimicrobial activity of some newly substituted 2-mercapto3-phenyl-4 (3H)-quinazolinone. Iraqi Journal of Science. 2014;55(2Supplement):582-93.

22. Gyogyszer C, Vegeyeszeti E, Termekek RT, Gyara, (EP 789583) (1958).

23. Arslan O, Küfrevioğlu ÖI, Nalbantoğlu B. Synthesis and investigation of inhibition effects of new carbonic anhydrase inhibitors. Bioorganic \& medicinal chemistry. 1997 Mar 1;5(3):515-8.

24. Shan P. Mohammed*, Namsheer B, Dr.Jyoti harindran, Beena Thomas and Mithun K. Sebastian, evaluation of analgesic and antioxidant activities of Schiff bases, the europian journal of pharmaceutical and medical research, 2016;3(4), 418-424.

25. Chaaban, I., and Oji., O.O., 1984. Synthesis and antibacterial activity of 3-(2-aryl amino1,3,4thiadiazoles-5-yl) 4-hydroxy-4-substituted sulphamoyl benzene., J.Indian Chem. Soc., LXI, $523 \mathrm{p}$.

26. Muhi-Eldeen Z., Al-Jawad F., Eldin S., Abdulkader S., Ghantous H. and Garabet M., Eur. J. Med. Chem. Ther, 1982;17(5), 479.

27. Chaaban I, Oji OO," synthesis and antibacterial activity of 3-(2-aryl amino-1,3,4-thiadiazole-5yl) 4-hydroxy-4-substituted sulphamoyl benzene", Indian.J. Chem.Soc.,1984;LXI:523.

28. Smith, M. B. and March, J., " March's Advanced Organic Chemistry" (6thed), chapter16, John Wiley and Sons, Inc., New Jersey, U.S.A., 2007, pp 1407-1410.

29. John McMurry, organic chemistry, seventh edition published by physical science, David Harris in USA 2008; 710-711.

30. Clayden, j. Greeves, n. Warren, s. wothers, P. (eds:): amines react with carbonyl compounds. In: organic chemistry. Oxford university press inc., New York, 2001, pp 349-352. 